\title{
Digital Collage, Poster Design and Stephan Bundi: The Semiotic Analysis of Theatre Posters
}

\author{
Gürkan Gökaşan, Near East University, North Cyprus
}

\begin{abstract}
The aim of this study is to assess the single expression in approaching the traditional and digital methods for the design of cultural based posters like theatrical posters in consideration with the posters as a graphic design tool. The digital collage, which is the way of expression created in the early $20^{\text {th }}$ century by the art movements and artists using collage as aroused on the computer screens other than canvas through the technology, has also been used in graphic design. The digital collage facilitates the reflection of artist's imagination to the screen by means of technology, allows the traditional collage to be used together with the digital. The semiotic analysis of theatre posters designed by Stephan Bundi between the years of 20122015, who is considered as the one of the first users of these two methods, was conducted within the scope of study. The graphic codes utilized were analysed and the climaxes in the theatrical scripts were addressed in a single expression with these two styles. The posters designed within this period by Bundi, who had used the traditional collage and digital collage that considered as two different ways of expression in his cultural posters, were analysed on the basis of Peircian sign theory, through the use of icon, index and symbols, and their interpretation was elaborated accordingly. As a result of this study, the findings indicated that Bundi made two different styles into one way of expression, used the traditional methods together with digital collage in graphic design, chose the colour in posters in accordance with the content of play and interpreted the content in the cultural posters designed by the poster designer with his own style through digital collage method. In consideration with the analysed posters of Bundi, his frequent use of icon that is given under the Peircian sign theory was stood out.
\end{abstract}

Keywords: Graphic Design, Poster, Stephan Bundi, Digital Collage, Cultural Posters, Theatre Posters 


\section{Introduction}

Poster can in general be defined as a picture placard prepared to announce or publicize something that hung where people can see easily.Rather than the word "afiş" as used in Turkish from the origin of French "affiche", the word is used as "poster" in English. Both words are used in Turkish. Poster is translated to "plakat" in German. Poster is one of the effective graphic design tools in transmission of information within the context of announcement and reaching the masses in our daily lives (Özmutlu, A., \&Kaptan, 2009)

Thus while affiche or poster represent the same purpose in use, they are only referred in two words. Posters, used in very comprehensive spectrum from propaganda, theatre plays to the cinema, and consumption and service products may influence large masses depending on where they are hung.

Pursuant to Özkan(2003),posters are one of the media tools that accomplish to remind the message within and attract attention. The posters, which have a privileged position among the messages of graphic arts, reflect the characteristics of the country that they are designed/produced, on the walls and boards. Hence, they are the graphic objects that publicise the massages concerning the structure of society (Agsakalli, 2014).

The posters as created on the basis of design and artistic thinking, are divided into categories such as politics, social, commercial and cultural; therefore they may be considered as the notices that are organised in accordance with the needs of social structure and prepared in the transmission of advertisements.Everyday we see various advertisement images in the cities that we live in; while turning a page, going around the corner or passing by us very fast. We are used to seeing such images that it is not so much possible to identify the complete impacts on us. As Berger indicated, such advertisement images that have surrounded us all around might be everywhere, yet it is inevitable that they have different features and styles (Berger, 2008).

The advertisement posters, one of the effective ways to allow the advertisements reach the masses have been the domain of printed advertisement means. The advertisement posters used to promote a product or service are used to provide information to the masses, persuade regarding such product/service and guidance (Parsa, 2007). 
The poster designs covering the cultural events such as festival, theatre, cinema and symposium might also be discussed under the subject of cultural posters(Lucie-Smith, Kiliç, Kovulmaz, \& Akınhay, 2004). A poster designer may follow much 'free' way in the design of cultural posters, thus it would be possible to reach various target groups and the design of poster would become 'unique' in terms of the content and style. The composition with various elements created by the event aimed for promotion is an indicator that the artist can think indefinite and can reflect this on the poster. The artist may take the audience to 'an intellectual' adventure through the reflection of imagination on the poster (Işik, 2010).

Social posters that are related with the majority of society may covers the issues of health, traffic as well as may be designed for different charity organisations. The social posters that are mainly designed to inform, warn and motivate the public aim an effective communication with the society through using the basis of human psychology and visual communication. With the development of multiplication techniques, the states used such poster types during the World War I and II in order to keep their communities together, encouragement and awareness (Özkirişçi, 2016).

The aim of this study is to identify the contribution of Stephan Bundi, who is particularly known for his cultural posters, through the analysis of graphic design codes used in the theatre posters.

\section{Theoretical Framework: Digital collage, poster designand Stephan Bundi}

\section{Historical Background of Poster Designs}

The history of design goes back to the figures in caves and invention of writing; hence the design shall not be considered separately than the printing art and technology in the graphic art (Yalur, 2014).

When it comes to the poster designs in the world, many countries may stand up, however the distribution of analysed posters on the basis of countries should be performed in consideration with the socio-economic status, culture, education status, history and subjects that influence the country. The formation of design on the basis of countries may be considered in parallel with art; which may vary from the colour, font type, style of design element and illustration style. 
The poster defined as an art form has been applicable as a way of expression since its occurrence and pushes the boundaries of drawing (Gumustekin, 2013).

As indicated by Ertep (2007), the design, which is the message and way of delivering the message, of a poster may be considered as the most crucial element to have impact on the existence of a poster. Although tastes different, no doubt that a badly designed poster is not acceptable. Each element comprising the picture, photo, colour etc. has an essential part in the success of poster (Gumustekin, 2013).

The posters, which are defined as a design product rising in value over time, are used for the purposes of propaganda and advertisement. The black-white graphic design products produced until the invention of colour lithography by AloisSenefelder in 1798 (İncearık, 2012) have been visually effective with the use of colour.

In consideration with many resources, the abstract posters had been developed with the World War I. El Lissitskywas one of the leading artists of abstract posters, a Soviet architect and painter born in 1890 known to be around by the Soviet October Revolution. Similarly, the German School of Bauhaus also brought innovations in industrial design and town planning as well as in architecture, created a new architectural movement and influenced all domains of art.

According to many philosophers, the strong compositions where the influence of purism and cubism were explicitly observed post-World War II reflected the difference in the products created after two wars. Although the World War II had an influence on the new technique of John Heartfield (Bostanc1,2012), who had a significant position in the art history of $20^{\text {th }}$ century and worked on the book cover designs prior to Berlin Dada Movement by using his advertisement education as well as is known for his works of photomontage art that pieces of photography are combined one another, there was no other innovation brought by the World War II. However, the development of photography art after the war had an indirect impact on the poster works. 


\section{Digital Collage and Role of Graphic Design in Poster Design}

The word of collage originated from French and used to define the art works created by sticking the materials such as paper etc. was derived by adding the suffix -age to the word "coller", which is the word "to stick". This art marked a surprising era in the plastic arts by sticking different irrelevant objects on the painting. Firstly, "sticker papers", such as press clippings and envelopes then matches and cigarette boxes, pieces of wood and metal plates were used (GroilerInternational Americana, 1993).

Digital, the term of numerical has been introduced into our lives with the use of mechanic pieces such as machines and computers, which the computers may be considered as the most popular example. The technologies developed via the computers facilitate the life and allow saving time. Considering the evolution of graphic design in time, the works created with traditional methods consume so much time. The advertisement and graphic design in private sector developing in parallel with the developing technology is the locomotive of this sector. Hence, the use of computer and other technologic equipment saves significant time. The concept of 'digital collage' that may revive the historic adventure of collage provides an opportunity to the artist to create his/her imagination in a shorter time with higher trial and error tolerance.

As much as the importance of poster, the quality of graphic design on the poster can allow the appropriate transmission of the message. The priority in the poster design is related with the content of message and target group to be addressed. Similar to the other communication tools, the space for the transmission of message is limited. This space shall be used as effective as possible and the message, slogan and story shall go hand in hand. Additionally, the clear objectives and universal design approach can be indicative components in the poster design.

In the poster design, the graphic design is being used more effectively. After the computers have been introduced into our lives, shaping the designs by blending the technology with art positively affect the time, economy and creativity of designer. Moreover, technology has an effective influence on the creation of various poster design alternatives. 
The main design elements in the poster design are colour, typography, illustration and/or photography. The hierarchical order in the poster design shall be considered as obligatory for a successful outcome. For instance; the use of solely text or visuals emphatically, instead of equal use of visual and text may create more effective, clear and successful poster design. If colour is found as the priority object of the audience in a poster, then the design should include attention-grabbing colours (Ambrosse, \& Harris, 2013). The reason for this might be that the eye perceives the colour first than the style. The other visual and typographical elements should be used in parallel with the subject; hence the outcome in designs would be more successful, effective and aesthetic.

\section{Stephan Bundi -Graphic Designer}

Stephan Gundi, who is a Swedish Graphic Designer and Art Director, has specifically designed the cultural and artistic posters for theatre, biennale and opera. According to Bundi, who has more 100 world-famous awards particularly Red Dot with his works exhibited at MoMA (Museum of Modern Art), the heading and content in a poster design lead an effective design. The technique used in shaping the content, the story and catching the attention of target group have a vital role in the poster design. Stephan Bundi, who used both traditional techniques and digital space with the developing technology, emphasizes the importance of technology in terms of saving time and technical facilities. Therefore, it is possible to address that the artist becomes much free in reflection the imagination on the poster with less boundaries (Gokasanand Dag, 2014).

\section{Method}

\section{Data Analysis}

Semiotics is a science that ensures the evaluation and analysis of all elements covering the interpretation, establishment or comprehension of indicators. It is an interdisciplinary discipline that brings many sciences and disciplines like semantics, phonetics, architecture, sociology and psychoanalysis. The word semiotics is derived from the word 'semeion' which mean 'sign' in ancient Greek language. Namely, the semiotics known as the sign science is considered as the discipline assessing the codes and structuring of codes. 
The leading people of semiotics are Ferdinand de Saussure, Roland Barthes and Charles Peirce. Peirce as the basis of this study developed the idea of Saussure in semiotics and considered the sign, object and interpretant as the basis.

The semiotics theory of Peirce as a basis for the data analysis of this study is known by the categorisation of icon, index and symbol. Therefore; the relation between the sign and signified can be analysed in three ways. One of such is the signs i.e. symbols that are acknowledged and used regardless of no traditional relation between the sign and signified; and index indicating the sensory related relation between the signifier and signified. Eventually Pierce addressed the icon i.e. iconic sign where the signifier is the image or copy of signified.

Within this perspective, this study will discuss the use and interpretation of icon, index and symbols in theatre posters by Stephan Bundi.

\section{Case study}

This study analysed the graphic design codes used by Stephan Bundi, particularly known by the cultural posters, in theatre posters. Therefore, the total of 9 posters of Bundi designed between the years of 2012-2015 and published on his own website were analysed through the semiotic method.

\section{Data collection}

Within the aim of this study, the new age theatre posters of the artist Stephan Bundi published on his own website between the years of 2012-2014 asDon Carlos [Don Carlos], Ephebiphobia [Ephebophobia], Faulen Julie [Miss Julie], Der Got Des Gemetzels [God of Carnage], Lachen Verboten [No Laughing Allowed], Der Menschenfeind [The Misanthrope], Rot[Red], Der Theater-Macher [The Theatre Maker], Der Man in Der MadeWanneoderwie Man ein Held wird [The man in the bathtub - or how to become a hero].

\section{Limitations}

As indicated above, this study discussed the new age works of Bundi, who has already many other works, published on his official website between the years of 2012-2015 prepared for the theatre among his cultural posters. 
The semiotic limitation of this study had already been indicated. Therefore, the study based only on Peirce among the semiotics theorists will analyse to find an outcome through the analysis of aesthetic codes used in his works.

\section{Findings and evaluation: Theatre poster works of Stephan Bundi}

\section{Findings}

\section{Don Carlos [Don Carlos]}

Designed by Stephan Bundi in 2012, the theatre poster namedDon Carlosstands out with the use of cool tones. The design with the use of acrylic and vectorial illustrations on the same surface is comprised of a castle (icon), crown (icon), an adult man face from side profile and the silhouette next to this male profile (icon).

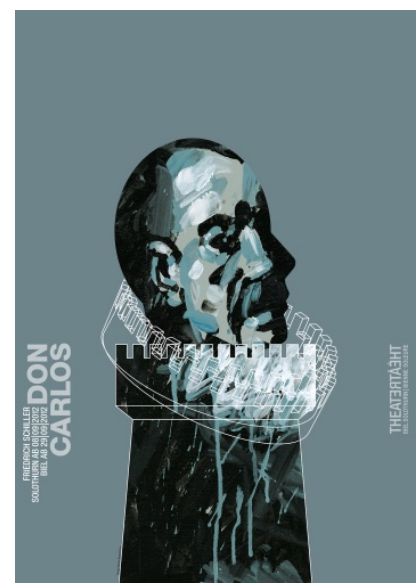

Figure 1. Don Carlos, 2012 (Bundi, officialWebsite)

Where the design merged the castle with the body of male image, the colours of black and white were used to create a contract to the surface. The visual covers $2 / 3$ of the poster with and associated typography written by sans serif and bold.

\section{Fraulen Julie [Miss Julie]}

The use of cool and warm toned colours on the theatre poster of Fraulen Julie, or Miss Julie is visualised with the women legs shaped with vectorial illustration. The female figure with high heels (icon) might be observed as wearing a short skirt/dress or being naked. 


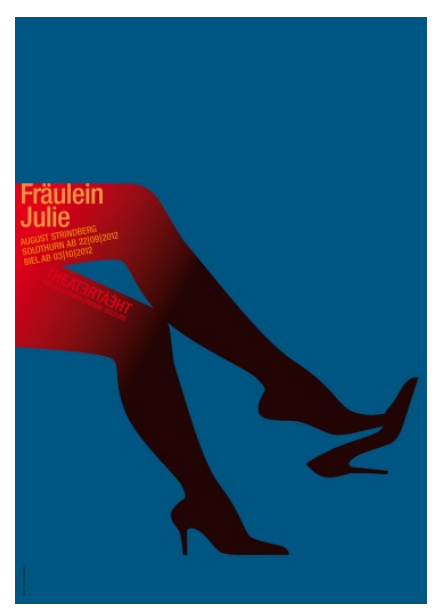

Figure 2. FraulenJulie2012 (Bundi, officialWebsite)

As the blue is chosen as the background colour, there is a transition from red to black (index) from the waist to the feet of woman. The typography of poster is a yellow text on a red background in sans-serif regular font.

Der Man in Der Made-Wanneoderwie Man ein Held wird[The man in the bathtub - or how to become a hero]

The poster, which was designed in the way to let us the bottom of the man bathing in the tub, might indicate from the pruney feet that he might be in the bathtub for a long time. A majority part of the poster, which has white in one half and light green in the other of the background colour, is the feet (icon) as the visual element.

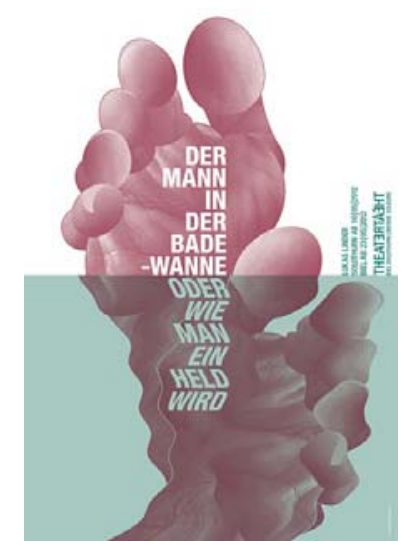

Figure 3. Der Man in Der Made-Wanneoderwie Man einHeldwird, 2012 (Bundi, officialWebsite) 
The issue of long theatre name had been practically solved by the position on the poster. The typography was chosen in a vertical form with total 12 lines, 6 of which were written by sansserif and bold, whereas the remaining 6 was written in italics; and their deformed form had given a strong impact on the poster.

\section{Der Got Des Gemetzels [God of Carnage]}

This poster, designed in 2013 by Bundi, is mainly in black, white and red. In consideration of the typography as the basis in this poster, the extra-bold and sans-serif fonts were organised in 5 lines aligned from the right, which were written on a white background with vertical cuts (icon).

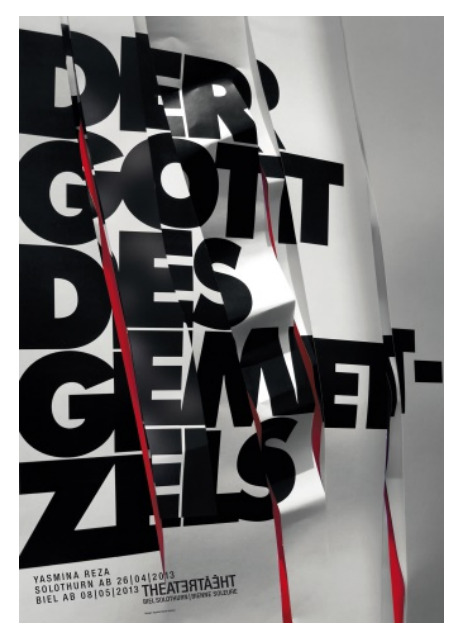

Figure 4. GotDesGemetzels, 2013 (Bundi, officialWebsite)

The thick and strong nature of font and the cuts on the surface did not make any negative impact in reading the text and letters, while such cut effects created a three dimensional view on the poster in places.

\section{Der Theater-Macher [The Theatre Maker]}

The visual elements distributed on the poster in the colours of grey, black and white background, is the image of the bottom part of light bulb (icon) and scattered black paint (index). There are big of black paint patches with a big black paint at the centre, and the other dots are spread from this centre. 


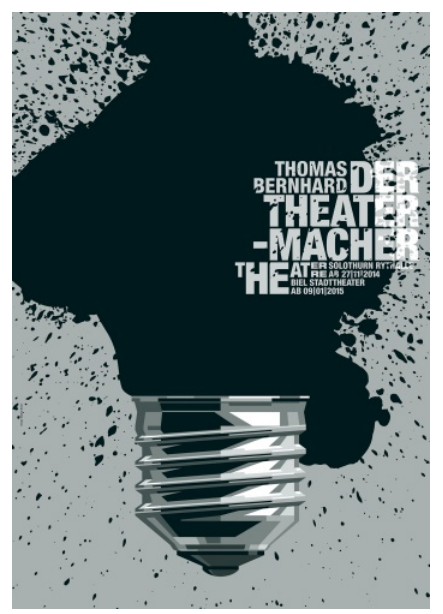

Figure 5. Theater-Macher 2014 (Bundi, officialWebsite)

The bold font used on the middle-right of porter is in the same colour of the background as grey that allows seeing the scattered black paint. The digital illustration is conceived in the design of poster.

\section{Rot [Red]}

With the illustration placed on the almost-complete poster, the empty paint tube (icon) created integration with the background colour with the empty section in the middle. The poster illustrated a tube squeezed from the middle but at the same time all gone with no lid.

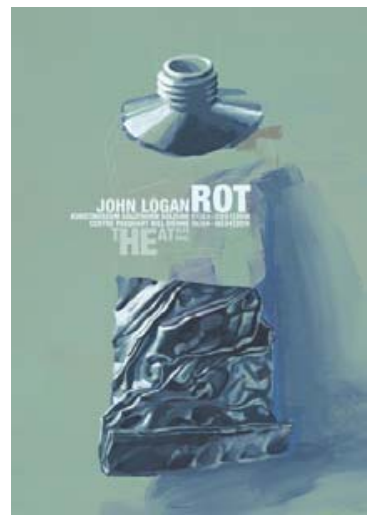

Figure 6. Rot 2014 (Bundi, officialWebsite)

The typography was analysed on the upper part of tube with sans-serif fonts. Green and shades of green were chosen on the background with vertical blue brush strokes (index) and light red brush effect on the upper part of the tube. The creases on the bottom part of tube create the idea that the tube was tube for several times. 


\section{Ephebiphobia [Ephebophobia]}

The poster designed for the Ephebiphobia, which is defined as the fear of youth, includes a black and white Converse brand with loose shoelaces (icon).Looking as a worn shoe, it looks like as if used too many times and the flap of the shoe is similar to a real tongue in grey.

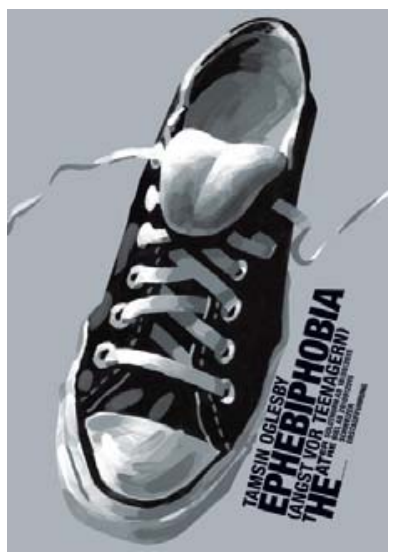

Figure 7. Ephebiphobia, 2015 (Bundi, officialWebsite)

Similar to the other posters, the typography is in a sans serif and bold font. The information is written in black on a dark grey colour in a cross angle whereas 'Ephebiphobia' is written in bold and bigger than other writings.

\section{Lachen Verboten [No Laughing Allowed]}

Bundi had chosen to use the pastel tones in his design for the poster 'No Laughing Allowed' as in his many other posters. An image of a coloured stone starting from the centre-top part of the poster that contrasts with the pastel pink background is used as an illustration.

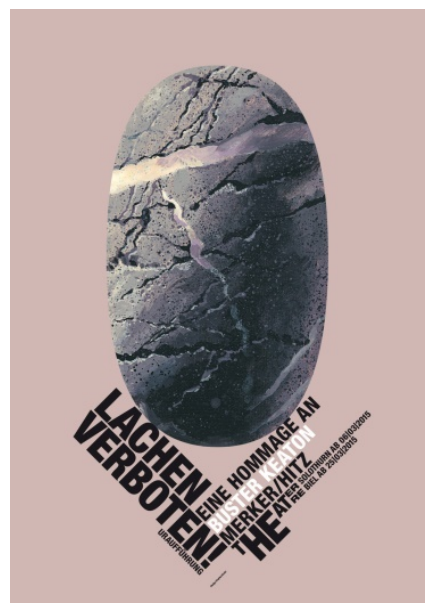

Figure 8. LachenVerboten, 2015 (Bundi, officialWebsite) 
There is a vertical and horizontal line from the crack on the stone (icon) that is in the lighter colour than the background. The pattern with darker coloured cracks might indicate a worn out stone. The name of theatre and other information placed under the visual of stone written in sans and cross with black and white.

\section{Der Menschenfeind [The Misanthrope]}

Designed by Stephan Bundi in 2015, the theatre poster of 'Der Menschenfeind' has a dark pink background. One of the most interesting aspects in the naked man illustration (icon) placed on this background is that the man does not have above his elbow. The poster with the spine placed vertically in white square dots has brush strokes.

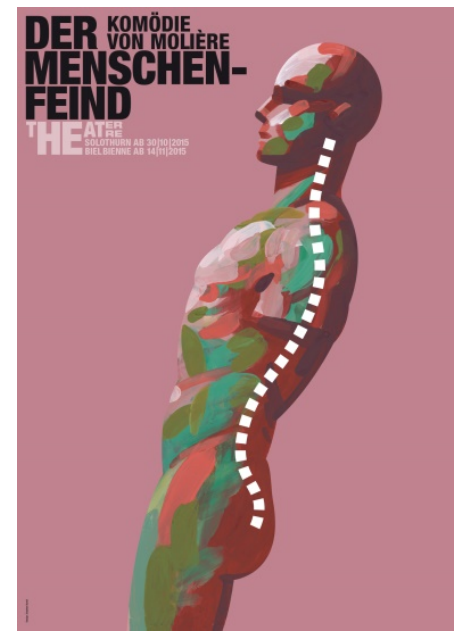

Figure 9. Der Menschenfeind, 2015 (Bundi, officialWebsite)

The male figure illustrated from above his knees is bald. The typography created on the topleft part in serif fonts is used in black on the top, while the part with the name of theatre was written in the lighter tone of background.

\section{Evaluation}

\section{Semiotic Analysis of the Poster of Don Carlos [Don Carlos]}

The genre of play as tragedy is obvious from the cool tones used on the poster. The cool colour mainly represent the calmness, trust, comfort and drowsiness (Özer, 2012).

While the use of acrylic painting represents the traditional approach, the castle and walls shaped with the vectorial design is in accordance with the existing graphic design. When the silhouette placed next to the visual of king, a silhouette of woman appears. The reasoning 
behind the integrated female and male silhouettes might be that the former fiancée of Don Carlos had become the stepmother of him and he did not ever forget her. The image of Don Carlos nested into the castle symbolises that he is a prisoner in the castle.

\section{Fraulein Julie [Miss Julie]}

There is a transition from red to black starting from the sexual organ of woman to her feet. Considering the colour of red on the genital recalls the sexual desire, this can be interpreted as 'Miss Julie' uses her femininity effectively. As the figure wears stilettos, the shoe on her right foot was placed on her fingertips inviting for the intercourse. The straight position of left leg and right foot leaning ahead might be considered as the woman was about to seduce the man. Looking at this image, the female figure sitting up straight is ready for the intercourse and the stimulant of her sexual organ is active. Therefore, it is possible to illustrate a woman who is confident and dominant on her man with her femininity.

\section{Der Man in Der Made-Wanneoderwie Man ein Held wird[The Man in the Bathtub - or How to Become A Hero]}

The skin deformations occur when the human body stays in water for a long time. This poster, which describes a man in a bathtub, illustrates a man with pruney feet. Considering that half of the poster in green represents inside the water, the white part represents the air.

\section{Der Got Des Gemetzels [God of Carnage]}

In the poster for the play called the God of Carnage, the colour of red under the vertical cuts on the white background represents the blood and murders. The upper part, which was carefully torn apart with a knife or another sharp object, hides the red i.e. the murders/deaths. Not from the position of cuts but moving to another direction, wind or another external factor might scatter these pieces. When looked carefully, the white background has two layers. In consideration with the name of play, there might be a murderer with more than murders committed professionally. Drawing an analogy to 'God' represents inaccessibility, obscurity, supremacy, punisher and immunity, which might lead us the character of murderer.

\section{Der Theater-Macher [The Theatre Maker]}

The object, dominant on the poster and resembling a light bulb, represent the concepts such as creativity, idea and enlightenment. The light bulbs give out light and enlighten the 
surrounding pursuant to the mechanism on the glass part. However, instead of a glass part on this light bulb, there are little black dots all around, which may indicate that the issues as creativity and idea fell apart or disappeared. With a different perspective, this source of light was broken with a hard object and spattered the black colour (negativity, sadness etc.) around.

\section{Rot [Red]}

In the theatre poster named 'Red' which is about the famous painter Mark Rothko, The colour of red was not used directly.Bundi, who managed to lead people to look for the colour of red, used an empty paint tube and referred that the missing colour of red might be from that paint tube. Bundi might complement Rothko, who described his concern with "one day black would eat the red", with his image.

\section{Ephebiphobia[Ephebophobia]}

The visual on the poster that represents youth/being young with an old casual shoe gives one of the most important hints about the context of play named 'the fear of youth'. A rebel/protest was expressed through a single shoe with loose shoelaces and without the other one in the pair. The resemblance of the shoe flap with a real tongue signals that the play has a fun topic. Sticking out a tongue is generally considered as a sarcastic behaviour as 'an empathy' might be created with the shoe metaphor. The saying "put oneself in else's shoes" explains such circumstance.

\section{Lachen Verboten [No Laughing Allowed]}

The stone defines an object without any soul and movement. Bundi, who associated the function of stone with the name of play 'No Laughing Allowed' gives the feeling of long history and wear out in the stone.

\section{Der Menschenfeind [The Misanthrope]}

The male figure on the poster almost like a mannequin is bald with an athletic body but the arms are cut up to the wrists. Therefore, the visual could not use his hands and somewhat represented the despair. The geometrical structure of spine on the visual also attracted attention. 


\section{Conclusion and Recommendations}

\section{Conclusion}

As mentioned above, Özmutlu and Kaptan (2009) noted that the posters are utilized as an effectively used graphic design tool in the publicity and transmission of messages to large masses (Özmutlu, A., \&Kaptan, 2009).According to Özkan (2003) the posters, which have a privileged place among all other elements of graphic design, reflect the characteristics of country that they are designed in, on the walls and panels. Therefore, the messages regarding the structure of society are delivered to other masses through the graphic design (A $\breve{g s a k a l l i}$, 2014). Iş1k (2010), who noted that the artists designing the cultural posters such as for festivals, cinema and symposiums can think much free, stated that designing cultural posters and reflection of artist's imagination on the poster take the audience to an intellectual adventure (Iş1k, 2010).

Gümüştekin (2013) noted that the posters are defined as an art form and still survived as a different way of expression from the occurrence of posters up to now, and that they are pushing the limits of drawing (Gümüştekin, 2013).Upon the use of technology, which was adopted and used by Cubist, Dada and Surrealist artists in the early $20^{\text {th }}$ century, in the field of art, the techniques serving to appropriate the collage, editing and montage for oneself have become easier (Sağlamtimur, 2010). Therefore, the graphic designers can much easily reflect their imaginations on the screen.

In the theatre posters designed by the digital collage method, Stephan Bundi showed that the traditional collage and illustration technique integrated with the digital practices is possible and such method can be used as a way of expression. Bundi, who designed posters with traditional methods as well as the method of digital collage via the help of technology, blended two styles that can be interpreted separately on a common ground and transformed into a single style.

Unlike the collage technique used in the modern art, the colours and shapes are transferred on a computer screen rather than the canvas and the processes can be applied through specific graphic programs. While the artists get benefits from the opportunities of technology, they also think freely in their expression when compared with the traditional techniques.in the 
digital era, the collage technique evolves to the digital and minimize the limits of imagination.

Bundi preferred to use the font Sans-serif in the typography for his theatre poster works and in all the analysed posters, the name of plays were written much bold and in bigger font. Hence, Bundi analysed the typography of names and other information related with the play in a certain hierarchical order.

In the analysed theatre posters, Bundi visualized the peak moments from the play and followed the context of theatre scripts; such peak moments were analysed with the semiotic analysis. The colours in the posters were chosen in consideration with the tension in the play, and the whole story was assessed far from complication through indicators and colours.

Stephan Bundi, who is considered as one of the people using the traditional methods in the graphic design, has utilized the means of technology and determined his style with two different methods. Among the posters of Bundi, which were analysed under this study, he used icon more specifically from the Peirce's Theory of Signs.

\section{Recommendations}

Other cultural and artistic posters can be analysed in addition to this study, which assessed the theatre posters of Stephan Bundi using digital and traditional illustration methods in the graphic design. Another study to be conducted on the poster works of Bundi in relation with his general style and analysing the reasons and ways in using signs and elements would provide significant findings in understanding Bundi.

In a new study that might assess the cultural posters other than the ones between the years of 2012-2015, the subjects as the relation of typography in posters with the illustrations and colours; and the analysis of fonts used in posters in a typographical approach and the relation of fonts with content can be covered.

Additionally, the methodology and semiotic style in the poster designs of Bundi for opera and musicals might also be analysed together with the signs respectively. 


\section{References}

Ağsakalli, M. S. (2014). Sürrealizm Akiminin Afiş Tasarimina Etkisi Ve Uygulama Örnekleri (DoctoralDissertation). Atatürk Üniversitesi, Erzurum/ Turkey

Ambrose, G., Harris, P., \&Bathana, B. (2010). Görsel grafik tasarım sözlügüu. Literatür Yayınları.

Ambrosse, G.,\& Harris, P. (2013). Grafik Tasarımda Renk. (1. Basım) Bengisu Bayrak (Çeviren). İstanbul: Literatür Yayınları, 106,108-128

Berger, J. (2008). Görme Biçimleri, Çev. Yurdanur Salman, Metis Yayınları, Đstanbul.

Bostanc1, M., (2012). John heartfield ve nesne yorumu. İstanbul: Işıłk Üniversitesi Sosyal Bilimler Enstitüsü.

Ertep, H. (2007). Gündelik Yaşamımızın Ucundan Tutunan Bir Tasarım Nesnesi:

Afiş. Grafik Tasarım: Görsel İletişim Kültürü Dergisi, 13, 80.

Gokasan, G. \& Dağ, H. (2014). Stephan Bundi ile söyleşi. Grafik Tasarım Dergisi, S.61, Istanbul: Arşiv Yayıncılık

GrolierIncorporated. (1993). The Encyclopedia Americana. Danbury, Conn: GrolierInc.

Gümüştekin, N. (2013). Rengin Bir Grafik Tasarım Ürünü Olarak Afişe Katkısı: Tarihsel Bir İnceleme.

I ncearı, M. E. (2011). Grafik tasarım rehberi. I stanbul: KODLAB.

Işik, D. (2010). Görsel İletişim Aracı Olarak Afiş Tasarımı: 2009 Yılı Yerel Seçimlerinde İzmir Buuyuskşehir Belediye Başkan Adaylarının Afiş Tasarımlarının GöstergebilimselÇözu mlemesi. Yu ksek Lisans Tezi. İzmir: Ege Üniversitesi Sosyal Bilimler Enstitu su

Lucie-Smith, E., Kılıç, E., Kovulmaz, B., \&Akınhay, O. (2004). 20. yüzyılda görsel sanatlar. Akbank Kültür Sanat Merkezi.

Özer, D. (2012). Toplumsal düzenin oluşmasında renk ve iletişim. Sosyal Bilimler Araştırmaları Dergisi, 6, 265-281.

Özkirişçi, İ. H. (2016). Tiyatro Afişlerinin Grafik Tasarimda Görsel AlgiAçisindan İncelenmesi Ve Hareketli Afiş̧ Uygulamalari. Hacettepe Üniversitesi Güzel Sanatlar Enstitüsü Grafik Anasanat Dalı, Ankara.

Özmutlu, A.,\& Kaptan, A. Y. (2009) Grafik Tasarim Atölye Derslerinde Afiş Konusunun Uygulama Ve Çözümleme Süreçlerinde Göstergebilimsel Çözümleme Yönteminin Kullanimi. (Unpublished Master thesis) Ondokuz Mayıs Üniversitesi, Samsun/ Turkey. 
Online Journal of Communication and Media Technologies Volume: 7 - Issue: 3 July - 2017

Parsa, A. F. (2007). İmgenin gücü ve görsel kültürün yükselişi. Fotografya Dergisi, 19, 1-10.

Sağlamtimur, Z. Ö. (2010). Dijital Sanat. Eskişehir: Anadolu Üniversitesi Sosyal Bilimler Dergisi.

Yalur, R. (2014). 1990-2013 yılları arasında afiş ve sosyal afişlerin grafik tasarım ve teknolojik açıdan incelenmesi (Doctoraldissertation, İstanbul Arel Üniversitesi). 